\title{
Improving Socio-Economy Potential Through Civil-Military Cooperation
}

\author{
Amarulla Octavian ${ }^{1}$, Lutfia Inggriani ${ }^{2}$ \\ \{amarulla.octavian@idu.ac.id ${ }^{1}$, lutfiainggriani38@gmail.com ${ }^{2}$ \} \\ Indonesia Defense University, Bogor, Indonesia ${ }^{1,2}$
}

\begin{abstract}
The development of military power in Indonesia is currently undergoing adjustments to upholding sovereignty which able to reach the entire territory of the Unitary Republic of Indonesia (NKRI). Through revisiting the context of current political discussion on the development of the Navy's military headquarters in Sorong city West Papua Province, this study analyses how government policy affects the socio-economic into the surrounding community using the soft-system methodology. Through economic sociology framework analysis, this article is expected to fill the gap between theoretical and methodological which often missed in previous studies. This article provides explanations of changes in market composition and consumption and also patterns and conflict control through civil-military synergy. This article also offers recommendations for Indonesia's Government to consider the development and construction of military power as an opportunity that will enable a spill-over effect on the economy and social stability.
\end{abstract}

Keywords: Socio-economic, civil-military cooperation, Indonesian Navy, spillover effect

\section{Introduction}

State development consists of two main aspects, which are total output growth and population growth. The total output of a country from the aggregate production of goods and services in a given year becomes a component forming the gross domestic product (GDP) of a nation. Because the output is produced through factors of production in the form of labor, capital, natural resources, and entrepreneurship (skill), these need to be properly managed to be used optimally. The regional economy certainly supports national development, the management of all available resources must be properly managed. Local economic development is placed based on the initiatives as well as the specific characteristics of the region concerned through the utilization of local resources (human resources, institutions, technology, natural resources, and capital), which strengthened by the ties of social capital. In the city of Sorong, all of this is still not adequately managed, so the development is still relatively slow. Social capital which mentioned is the stability of the community measured by the lack of conflict, bearing in mind that Papua is vulnerable to horizontal conflicts potentially disrupting the regional economy. 
To achieve the development of local economic potential needs to be supported with stability and security, in this case, this process can be called as part of peace enforcement that must be carried out by the military. This is not solely the work of the government and the community itself. The development of regional potential can be similarly compared to interconnected chain between human development, economic development, security stability, and enforcement of sovereignty; in which an external factor was intervening in form agencies engaged in the defense sector, namely the Navy, as one of the local economic driving factors. This role can be seen since earlier, in the era of and after the formation of military bases. In this case, the function and role of the Navy in the service of the State is realized when they present a sense of security for a State.

Although the Navy is a government agency engaged in the defense sector, but referring to Law 23 of 2004 in respect to the role of the TNI in Military Operations Other Than War (Operasi Militer Selain Perang - OMSP), the Navy is also required to play an active role in participating in the humanitarian, economic, social and cultural sector in accordance to the level. Although the CSO is considered as a social function of the TNI, there have not been many studies specifically on civil-military cooperation in the socio-economic field. The paper elaborated from this study offers a soft system methodology (SSM) as a methodological framework for evaluating and formulating suggestions from multiple stakeholders who separately pursue different objectives for increasing cooperation of the Indonesian Navy and Sorong City Government to optimize the regional socio-economic potential. SSM is a quality research procedure based on systems thinking and system concepts related to human activity systems. This methodology is used to understand the problem from different stakeholders' perspectives to gain a new conceptual idea to transform the factual phenomena (Hardjosoekarto, 2012, p.7). The use of SSM in this study offering an opportunity to answer theorist's problems while providing suggestions for actions needed by stakeholders.

\section{Soft System Methodology}

Checkland (as cited in J. Khisty 1995) introduced the idea of emergence as a corner-stone in system thinking. The principle of development states that whole entities exhibit properties that are meaningful only when attributed to the whole. Furthermore, Checkland added three more ideas to assemble the core concept on which system thinking is based: hierarchy, communication, and control [1] SSM is a qualitative research methodology, which is based on action research and systems thinking theory, and which places importance on meaning, selfreflexivity, interpretation, human experience, learning, and participation [2]

SSM as a methodological step offers an approach that tends to be experienced-based knowledge, meaning that it emphasizes on extracting information and the desire of actors in the real world be formulated into recommendations to improve the problematic situations that are the target of research [3]. To build knowledge from these experiences, SSM practitioners must be grounded in the conceptual framework and theories that become a standing position before the research is conducted Checkland [4]. This shows that the involvement of the writer as an SSM practitioner with a problematic situation can be defined scientifically. In this article, the theory of economic sociology proposed by Neil J. Smelser (2005) above is an intellectual framework that is used to analyze the role of a military institution with various defense activities can be an essential role for society and building the economy in general. 
One of the characteristics of SSM is that this method attempts to unravel the complexity of the problem by following the procedures and require stages of the analysis.

SSM originally consisted of seven stages, which are now compressed to four main stapes. The SSM process commences by exploring the problematical situation by identifying the issues, as well as analyzing the culture and power relations [5]. SSM consists of rich picture that can project how all stakeholders see problems in research, as well as interconnections and relationships between actors.

The second stage of SSM consists of constructing relevant purposeful activity models, which correspond to a specific worldview [6]. Root Definition (RD) helps the researcher in formulating activities in the thinking system to find a range of comparisons with reality in the field (real world), which is the main finding of the research. The root definition uses the QPR formula to answer the questions of what, why, and how, which ' $\mathrm{P}$ ' is the 'What'; ' $\mathrm{Q}$ ' is the' How'; and ' $R$ ' is the 'Why'.

CATWOE analysis is used further after the root definition at the SSM stage has been made. For the root definition to be used as a conceptual model, the root definition needs to be approved and refined with the CATWOE analysis tool. The CATWOE tool is a reminder (mnemonic) that translates the root definition, which is made capable of discussing relevant human activity systems that have been selected. Known as the CATWOE is then created, and is outlined below. ${ }^{2}$

Table 1. CATWOE Table

\begin{tabular}{ll}
\hline Customers & : Who are beneficiaries or victims. \\
Actors & : Who is responsible for the activities. \\
Transformation process & : Convert input to output. \\
Worldview & : General view that makes T meaningful. \\
Owners & : Who can prevent or change the activity. \\
Environmental constraints & : The elements out of the system. \\
\hline
\end{tabular}

After going through the stages of data collection, this study uses a qualitative approach with a descriptive research analysis so that the interpretation can be explained in more detail based on the facts that occur. SSM becomes a determining instrument in which the location of the problem is feasible to be discussed.

\section{Methodology}

This research uses a qualitative approach. Qualitative research aims to find out the specific meaning of phenomena based on participants' views. Qualitative research is a means to explore and understand the meaning of individuals or groups relating to social or human problems [7]. Researchers try to investigate issues related to the role of stakeholders in building civil-military cooperation to enhance the socio-economic potential in the City of

1 Checkland, P., \& Poulter, J.: Learning for action: A short definitive account of Soft Systems Methodology and its use for practitioners, teachers and students. Chichester, United Kingdom: Wiley. P.38 (2006)

${ }^{2}$ Ibid. p.42 
Sorong. To examine this issue, fragments of information were collected from various individuals as key informants by conducting semi-structured interviews, face-to-face meetings for at least one hour, conducted around the Navy headquarters, strategic defense areas in Sorong City, Sorong City Regional Government offices and random location of a residential area. Unstructured questions are created to enable stakeholders to offer more descriptions and perspectives to emerge. Interviews provide a platform for stakeholders to to express their views in a safe environment openly.

Research permission was obtained from the university to be given to those who participated in the interview and data collection process. All parties accept explanations and agreements detailing the research objectives, as well as the certainty that their participation is voluntary, that what they say will be kept confidential, and that they can withdraw from participation at any stage if they wish. Fieldwork consists of interviews and direct involvement in the activities of the object under study. Various stakeholders are involved in this interest.

Data and information collection was carried out in September to December 2018 to gain an initial understanding of soft tissue from a Navy perspective on the subject of military civilmilitary cooperation, local government understanding of socio-economic potential, community views on social conflict and economic problems, carried out at Indonesian Navy Headquarters, Sorong City Government, and Sorong City community. Interviews were conducted with two representatives from the Indonesian Navy Headquarters, four representatives from the Indonesian Navy in Sorong, two representatives from the Government of Sorong City, several local communities, and several business people who were randomly encountered in daily interactions. From the data and information collected analyzed using thematic analysis.

\section{Result}

\subsection{Problem situation}

Unstructured problem situations are examined through interviews to get an initial understanding of soft problems. In the first phase, SSM aims for researchers to experience the issues and investigate them from all perspectives. In the second stage, SSM is to express the situation of the problem, carried out by observing and directly involved in some open activities organized by the city government of Sorong, the Navy, and the community. This makes it possible to describe complex interactions between many actors. ${ }^{3}$ The Rich Picture makes it easy to identify problems. The researcher concludes the participants in a simple form, using a few words, and a pointer line to describe the reciprocal relationship between actors in Rich Pictures. The process of assigning these actors was obtained from field research: participants expressed their positions/institutions, explained their tasks, revealed the constraints faced, and expressed their interactions with each other about the issues raised.

The interaction and involvement of researchers in stakeholder groups in the Navy illustrate how they often experience obstacles that arise and how they overcome them with a holistic approach. Researchers see many things that need to be improved for the role of the

3 Checkland, P., \& Poulter, J.: Learning for action: A short definitive account of Soft Systems Methodology and its use for practitioners, teachers and students. Chichester, United Kingdom: Wiley. P.51(2006) 
Navy in addition to carrying out an active defense function, and they perform quite tiring tasks with special conditions in Papua making additional tasks of community development and social control necessary. The second stakeholder of the Sorong city government gave a positive view of the presence of the Navy in more significant numbers and is spread in several strategic areas in the City of Sorong. The researchers were directly involved in a number of open discussions with the city government to see how they established communication with the military in their area, indicating that awareness of civil-military synergy had formed there. Both parties recognize that changes in policies and regulations at the national and regional levels have influenced changes on the ground, especially in the patterns of cooperation developed between the civil-military so far.

The involvement of researchers with the community in interviews and several events illustrates the trust given to the Navy more than their confidence in the business industry. Stakeholders recognize that a fundamental problem that exists due to a lack of skills is the ability to deal with the extraordinary complexity that results from the interconnectedness between many players. The interdependence of stakeholders and the need for transparency, trust, and effective communication are highlighted as critical. After basing the results of field research and interviews, the researchers developed a rich picture, which is described as Figure [1]:

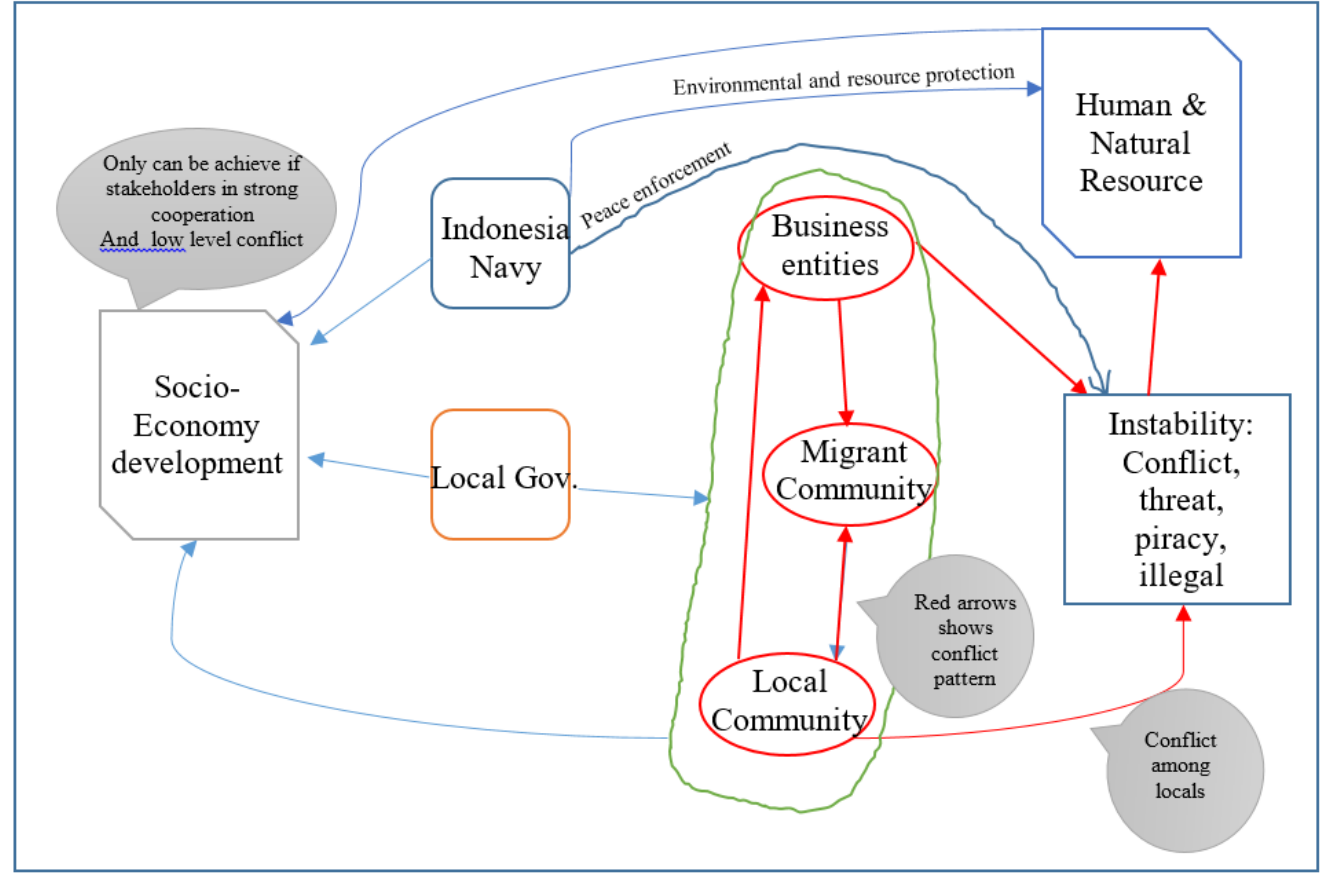

Fig 1. Rich Picture of Improving Socio-Economy Potential

Through the exploration of the opinions of the owners, namely the Indonesian Ministry of Defense, the Navy, the City Government of Sorong, and the City of Sorong, several statements, opinions, and problems were raised. The Indonesian Ministry of Defense basically 
realizes the urgency of developing the Indonesian Navy base to Eastern Indonesia, not only as part of the TNI's primary task of maintaining the sovereignty of the Republic of Indonesia and preventing threats, but there are other tasks as part of the CSOP which also make the TNI as an institution responsible for the community. The Navy, as an integral part of the TNI is in line with the Indonesian Ministry of Defense that the other functions of the TNI are not only in the defense sector. In the service of the Navy's OMSP, there is a social responsibility that contains the meaning of the fourth paragraph of the Preamble of the 1945 Constitution, including building a nation which in this case, highlights social and economic development. It can be said that the Navy carried out the mandate of the 1945 Constitution through programs organized through various policies on the organization within the Navy. In the actual implementation of the Navy's daily duties in carrying out the defense function it often faces outside technical constraints in the form of external disturbances, for example, horizontal conflicts in the community. ${ }^{4}$

According to the City Government of Sorong, there was a significant difference in the improvement of security and order in the border area in Sorong Raya after the addition of the Indonesian Navy, particularly Pasmar 3 in the Majener district. This section should be of concern to the government to synergize with the Indonesian Navy, especially in terms of counteracting the threat of horizontal conflict caused by separatist groups, terrorism, pirates, smuggling of goods in the sea territory, and the clashes that often occur due to customs issues. The Sorong City Government felt helped by the development of a strategic area, before the area that had previously been designated as an industrial zone had triggered conflicts among the public about the pros and cons of converting land to commercial industry. ${ }^{5}$ The decision finally changed when in 2018, a national strategic area (KSN) was developed, which was later transferred to a vital area for the military, where the Indonesian Navy developed the Koarmada III and Pasmar 3 bases.

"This is a rare phenomenon when indigenous people are willing to give up their land to become a military area. They prefer to hand over to the military rather than industry because they do not want genetic damage like in other areas of Papua, especially trauma due to Freeport." She says.

There are a number of different opinions found in Sorong City Communities, most of whom still adhere to the customs. These communities are scattered at several different points according to the location of the Indonesian Navy headquarters, and some think this is an opportunity to develop a home-based business to meet the demand for goods and services of troops serving in Sorong. Some others consider the Indonesian Navy to violate customary law with unclear reasons, usually they are motivated by personal motives to give conventional fines about land and plants that are on Indonesian Navy's property, the property is claimed as inherited land for their successors, their assumption that the Navy must repurchase it back to the next generation of landowners. ${ }^{6}$ This has become an obstacle between the local government of Sorong and the Navy to achieve efficient cooperation, because if people's behavior is not controlled, there will be many losses. As a result, the defense activities are not optimal because it burdens the budget, so that budget leaks often occur.

\footnotetext{
${ }^{4}$ Rear Admiral I.N.G. Ariawan, Commander of Fleet Command III, personal communication 29 November 2018

${ }^{5}$ Herlin Sasabone, Head of Economic Planning Bappeda of Sorong City, personal communication, 4 December 2018

${ }^{6}$ Thomas Jitmau, Head of Spatial Planning and Regional Affairs, personal communication, 3 December 2018
} 
The researcher assumed the role of the practitioner in applying SSM to address the issue. Rich picture transforms problems that were not initially structured into situations that are easily described and allows the selection of a solution system that is relevant to the question. Another use of rich picture is to identify the most critical issues, and then it can produce suitable systems related to problem-solving that are identified through data analysis as follows:

- Peace enforcement by the Navy

- Community development

- Safeguarding the natural and human resources

- Strengthening the role of local government

- Community acceptance

- Countering threat

- Regional planning

Of the seven systems that are considered relevant to overcome the problem, a system that can cover everything will be developed by analysing using CATWOE and root definition. These ideas will be presented to stakeholders to dig deeper into what steps are most important to do first is, stakeholders will be asked to choose the issues that are most worthy of attention. The result, based on information gathering from stakeholders, is Peace enforcement by the Navy, community development, countering threats, and safeguarding the natural and human resources.

\subsection{Root Definition and conceptual model}

This stage presents root definitions and The Conceptual Models that are appropriate to the system that must be built in increasing the socioeconomic potential in Sorong City, as shown in Figure [2] below:

Table 2. Root definition for a system that should be built to improve socio-economic potential

The function and the role of the Indonesian Navy to carry out the mandate of the 1945 Constitution, Law No.3 of 2003, and the oath of the Indonesian Navy's soldiers to OMSP through peace enforcement that is used to ward off threats, enforce the law for marine crimes, and community development in order to realize the synergy of civil-military cooperation in the City of Sorong so as to make the City of Sorong a stable City of security, threats can be resisted, and protect natural resources so that the potential factors of production can increase in economic value.

Table 3. CATWOE. (Checkland, 1991)

\begin{tabular}{l|l}
$\mathbf{C}$ & Sorong Communities and Sorong Local Government \\
$\mathbf{A}$ & Sorong Communities, Indonesian Navy, and Sorong Local Government \\
$\mathbf{T}$ & $\begin{array}{l}\text { The achievement of stable social conditions with a very minimal level of } \\
\text { conflict vulnerability by aligning defense institutions, civil institutions, } \\
\end{array}$ \\
communities, and industry to optimize socio-economic potential
\end{tabular}



W $\quad$ One of the factors that can increase the socio-economic potential of the city of Sorong is the establishment of civil-military collaboration through official government regulation guidelines and cooperation between stakeholders.
O Ministry of Defense, Indonesian Navy, Sorong City Govern
E $\quad-$ Coordination, consolidation, and collaboration between stakeholders
- Changes in political conditions that result in changes in government regulations
- Conflict

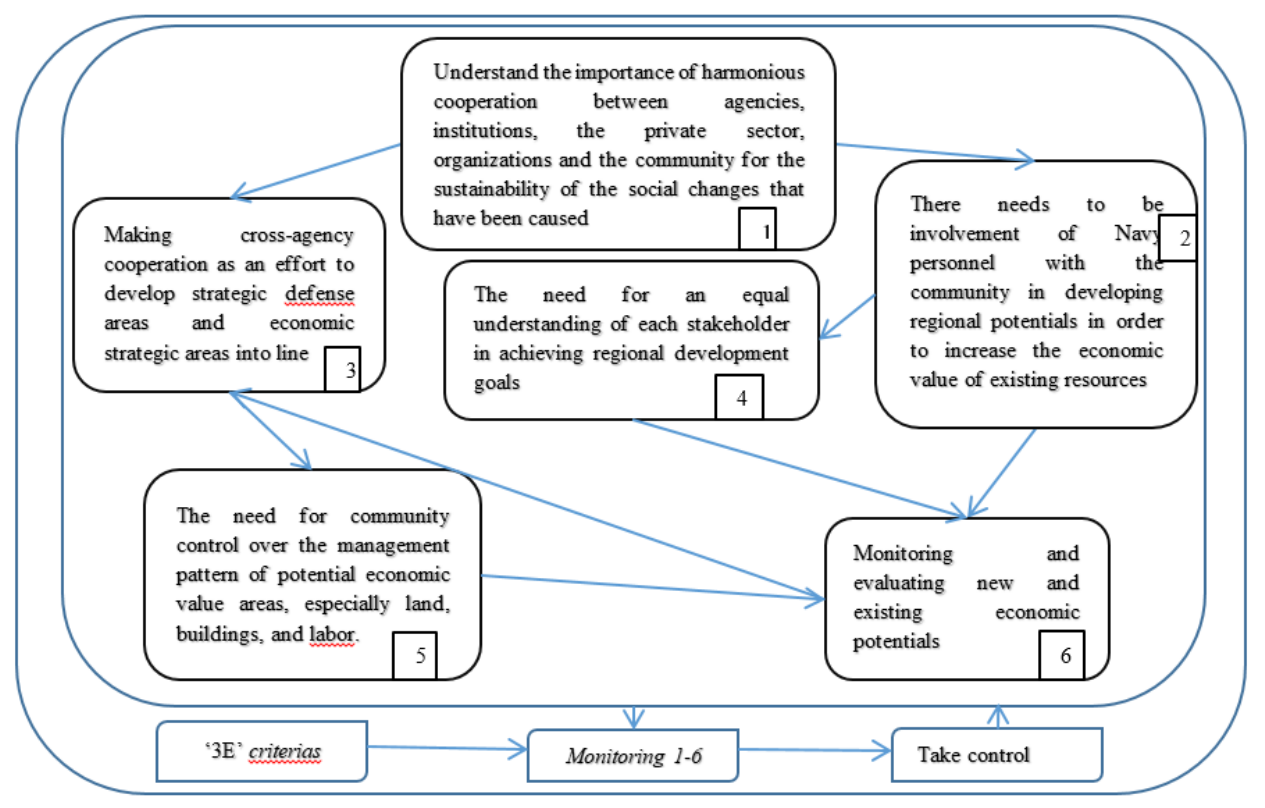

Fig 2. Conceptual model for a system that should be built to improve socio-economic potential

The conceptual model is presented in Figure 4. It is important to bear in mind that there is no right or wrong way of describing activity in conceptual models, and that it is about presenting descriptions derived from multiple, valid interpretations of viewing the world. ${ }^{7}$

\section{Discussion}

The use of SSM implicates various parties that have identified various problems that affect the general socio-economic conditions of Sorong City, as reflected in figure 1. The benefit of SSM is to emphasize that structural and social factors that can cause issues, can be

\footnotetext{
${ }^{7}$ Khisty, Jotin.: Soft-Systems Methodology As Learning And Management Tool. Journal of Urban Planning and Development 121(3) 4. (1995)
} 
structured identified. Through the SSM cycle, not only stakeholders in the military and local government can see these problems, but also the community who can be involved to jointly decide which issues are being addressed to improve in socio-economic conditions. The evaluation of the SSM process shows that stakeholders have favorable view of civil-military cooperation and have real synergy in making it happen.

In conflict theory, social change is not seen as a result of the process of adjusting values, still, it is seen as a result of the conflict that results in compromise and negotiation, so a mutual consensus is created differently from the initial conditions. Sorong City's situation before military bases was there, is often faced with various problems of subversion/infiltration as well as inter-tribal social conflicts, conflicts of political and armed separatist movements, sea crimes, and difficulties of violating boundaries [8]. The subversion/infiltration action was carried out by NGOs affiliated with Papuan separatist movements such as Political Separatist Groups (KSP) and Armed Separatist Groups (KSB) to show their existence. One of the social responsibilities undertaken by the Navy to be able to reduce these activities so as not to spread and provide further social impact on society. In Sorong City, multi-dimensional threats within the community are very diverse and vulnerable to other social problems. A large number of community groups in the social structure due to socioeconomic inequality will be overcome by government intervention or left to the market mechanism.

Economic inequality can be restored by regulating various financial instruments, while social arrangements with multiple impacts caused by conflict cannot be handed over to the market or government intervention without careful consideration, if there are wrong steps,s it will exacerbate the conflict and enlarge the deficit. One of the economic instruments that can be done by the government to overcome the deficit is by regulating prices. While social arrangements are about individual or group arrangements, for this reason, these changes can be overcome through government intervention by presenting the role of the military. This task is part of the mandate of law number 34 of 2004 concerning Military Operations Other Than War (OMSP), maintaining peace and social stability so as to create a social balance in controlling the confidence of industry players [9].

The role of the Navy's social control is a subtle approach that is in line with the exchange theory proposed by Hirshleifer. There are two first approaches based on contracts/agreements and methods based on conflict/coercion. In this case, the Navy through cooperation with the City Government of Sorong and community leaders who allow open space for agreement to create conditions of peace because there are considerations of exchange between preferences, opportunities, and perceptions, can be seen in the Potential Settlement Region (PSR) curve, shown in Figure [3] below: 


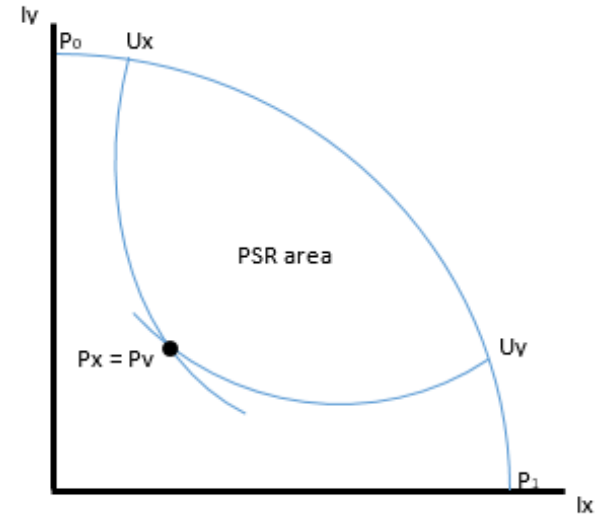

3a. Large potential settlement region (PSR).

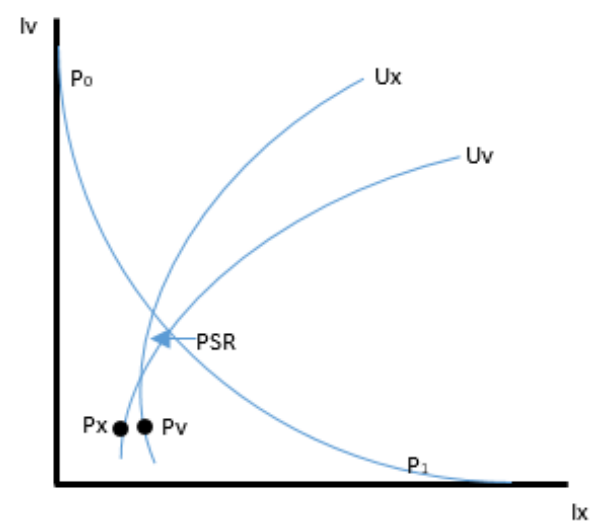

3b. mall potential settlement region (PSR).

Fig 3. Conflict and resolution curve. (Hisrshleifer, 1995)

The picture above is an elaboration of Hisrshleifer's theory to see the size of the space to negotiate to avoid conflict. The curve combines the elements that are the source of conflict to get space to be able to avoid conflict. As explained earlier, compromise and negotiation will create conditions that are different from the initial conditions. The initial conditions referred to instability and conflict-prone among the people of Sorong City, while the new conditions created are the result of government intervention through the role of the military in it as an effort to create space and balance points for peace from the disputing parties. There are three main elements trigger interaction in the process of conflict resolution, namely Preference, opportunity, and perception; the three components are expressed in the notations that form the curve.

The basic principles of production possibility curve (PPC curve) and indifference curve (IC curve) are applied to conflict conditions to achieve safe conditions, through illustrations with different interests of different parties notated through the $\mathrm{X}-\mathrm{Y}$ axis. Ix and Iy states the opportunity of the $\mathrm{C}$ (Ix), and the Y-axis represents the opportunity of the Y (Iy). The convex curve with P0 and P1 axes as the axis representing perception, where this perception is generally provided by parties offering peaceful conditions, in this case, the government, namely the Ministry of Defense who wants to realize national security stability through the role of the Navy and regional government. The same perception from both parties is essentially the same perception of peace or low-level conflict. The purpose of the Navy in the function of the police as a guardian of peace considering that the condition of the City of Sorong is not in the State of war and the conflict caused is still in the mild category and does not involve the combat whereas the local government as an objective civil control function applies the principle of Civilian Monito Unobtrusively or abbreviated as CMU-MS. CMU is interpreted as public monitoring is not prominent. The military evades the theory put forward by Peter D. Feaver [10]. This means showing substantial public control and superior civilian preferences. Then the P0-P1 curve is convex to give more room for choices and opportunities that can be taken by parties involved in conflict or dispute. 
On the Ux-Uy axis represents the element of choice (preference) which is the shape of the utility curve forming a positive slope in Figure 4.a and negative slope in Figure 3.b. Referring to the basic principle of this curve, there is a preferred choice between the two parties who want to achieve equilibrium with one of the parties having to decrease their choice (Ux axis) and the other party to increase their choice (Uv axis). When preferences are formed with the same perception, it means opening more extensive opportunities to achieve a state of peace. Py-Px forms an area that has the potential for higher settlement (potential settlement region, PSR). On the other hand, in Figure 4.b shows that the two disputing parties did not find the right choice to create an agreement, so that each of them raised their individual decision, it was seen that the Ux-Uy curve was curved upward. This creates a perception gap and makes the P1-P0 curve concave, as opportunities for resolution of conflicts or disputes become narrower because of the lack of equality.

In terms of the function of the police, Navy operations to provide military assistance to civilian forces are usually aimed at supporting domestic law enforcement at sea in a national jurisdiction. Defense Force Assistance for Civil Power involves assistance to civilian authorities, where they have inadequate resources or are not able to overcome the existing conditions at all. Maritime operations to provide military support to privat forces can include counter-terrorism operations such as offshore gas recovery or oil installations, or ships held by terrorists, or arms smuggling.

Conceptually, conflict theory explains that in every conflict, there is always a constructive, positive dimension if the results of a joint consensus are carried out by both parties. Therefore, all defense activities commanded by the Navy in Sorong City have accelerated the processes of social change that are better under the direct supervision of every Navy personnel. Of course, social change in the community for the better will also have an impact on the economic conditions in Sorong City significantly and positively. Thus, the industrial wheels in Sorong City will be faster. As its role as a social institution, the military is taking an essential part in society according to the navy function as a constabulator. Carrying out its duties as a significant component of national defense in its role as a regulator, the Indonesian Navy is tasked with securing the territorial waters of eastern Indonesia in the form of anti-piracy operations, EEZ tregional operations, water patrols, and enforcement of marine crimes.

Recorded from 2010 to 2014 with small units of the Indonesian Navy organization which at that time were still part of West Koarmada (currently Koarmada II) has been able to function as a guardian of sovereignty from leaking of incoming threats, attained actions on sea violations recorded at that time amounted to 434 types of violations. ${ }^{8}$ There are levels of work that can be taken from a peaceful attitude to an aggressive approach which can be called a maintenance step towards enforcement. The actions taken by the Navy in Sorong are environmental and resource management and protection actions, which protect marine resources. Fisheries protection is one of the oldest policing roles of naval forces and remains an essential activity in an era of extending jurisdiction and increasing exploitation of and stress on fish stocks in both coastal and oceanic waters.

Illegal fishing in the eastern region is common and not only detrimental to the state but the surrounding provinces that manage marine products. In 2014 and earlier, the northern part of Sorong City was not closely monitored, so according to data from the Indonesian Navy's Command Center and Control Center it was noted that the increase in crime dominated by

${ }^{8}$ Indonesia Navy Headquarter/ C2 Center, personal communication, 18 october 2018 
illegal fishing, human smuggling, and weapons trafficking. ${ }^{9}$ Military assignments in various regions have now been recognized as part of securing the area and the resources contained therein. A civil society consisting of people and government provides space for the military to carry out their duties by supporting local regulations issued by the local government. The general condition of Papua at this time has begun to open up, Sorong City as a representative of advanced civilization in Papua underwent a small-scale industrial revolution in its own environment and has included the role of the military in being part of the area. In 2017 the city government of Sorong formed a Spatial and Regional Plan with a reconfiguration of land allotments in Sorong divided into several strategic areas for civilian and military as shown in Figure [4] below

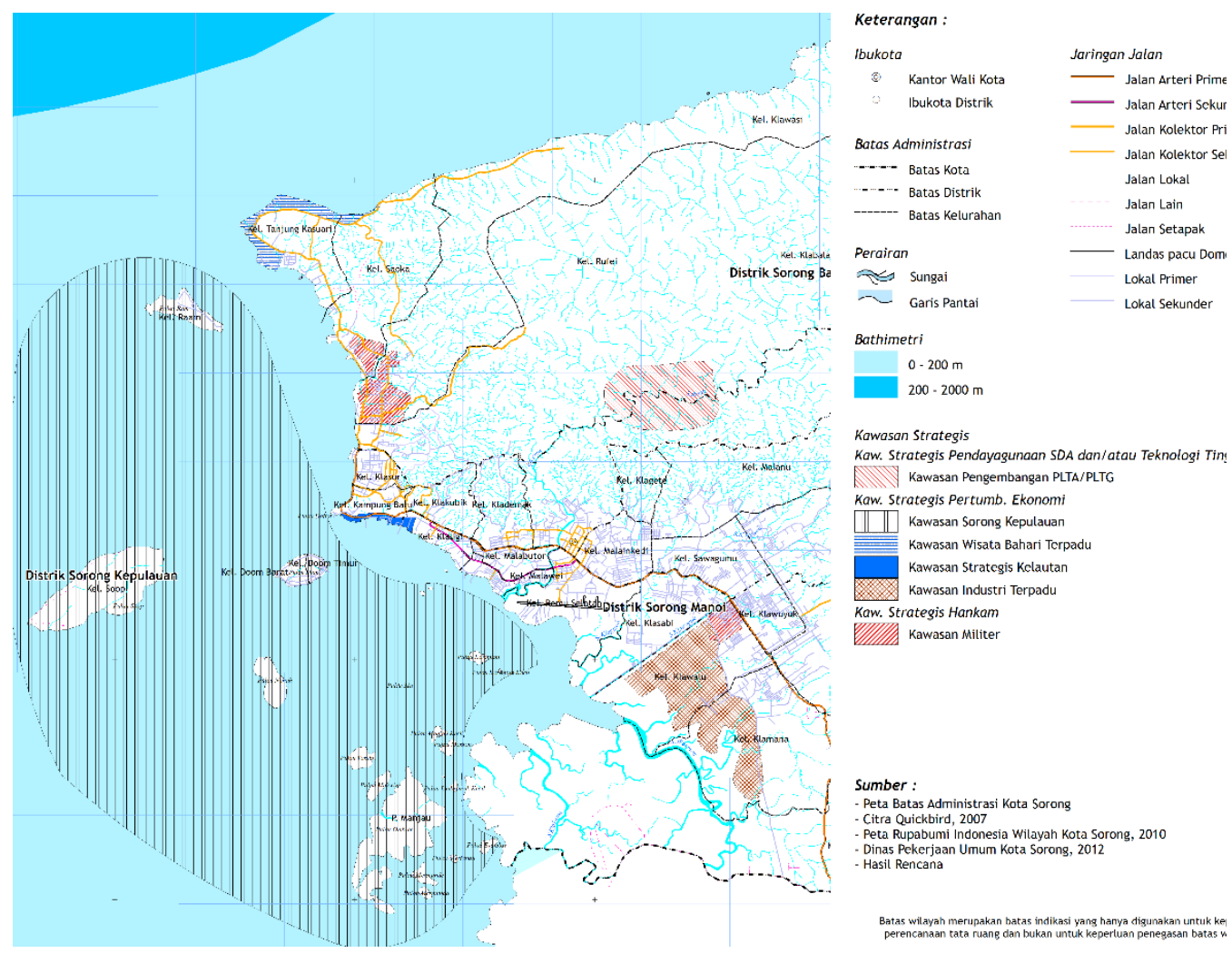

Fig 4. Rencana Tata Ruang dan Wilayah Strategis Kota Sorong. [16]

The map of the civil-military strategic region above shows the division of strategic areas used by civilians for commercial purposes, while the strategic areas used by the military for defense purposes. The vital area is divided into three, namely Strategic regions for the Utilization of Natural Resources and/or High Technology, Strategic Areas for Economic

${ }^{9}$ Ibid 
Growth, and Military Areas. These areas pay attention to the predetermined spatial structure. Spatial structure is the arrangement of settlement centers and infrastructure network systems and facilities that function as supporting social-economic activities of the society which hierarchically have functional relations. As a reference in the determination of strategic areas, criteria have been issued that can be used for the purposes of determining strategic cities, except strategic areas for national defense and security because they are of limited interest. Other vital areas are: Strategic areas for economic growth, socio-cultural strategic areas, strategic areas for the utilization of natural resources and,or high technology and/or environmental support functions and capacities.

Spatial planning for the city's strategic area needs to be prioritized because it has a significant influence in the scope of the district/city on the economic, social, cultural and / environmental aspects. The strategic area is an area in which activities take place which has an enormous influence on spatial planning in the surrounding area, other business in the same field and activities in different fields, and,or improving community welfare.

Types of strategic areas, among others, are strategic areas from the standpoint of economic growth, and the utilization of natural resources and,or high technology, as well as the functions and carrying capacity of the environment. he types of strategic areas in terms of economic growth are determined by the criteria of having a fast-growing economy, having a superior sector that can drive economic growth, having export potential, supported by a network of infrastructure and facilities supporting economic activities, having economic activities that utilize high technology, and functioning to maintain the level of food production in the context of realizing food security, and functioning to maintain the level of production of energy sources in the context of realizing national energy security; or determined to accelerate the growth of disadvantaged areas [15]. Regional development by arranging strategic areas at these locations is determined by efforts to minimize transportation costs between alternative locations under economic agglomeration (theory of minimum location costs) in order to support sustainable productivity.

The opening of this strategic area will make the value of externalities in state assets whose use can be utilized for the benefit of many people's lives and also adds value to its utility. Land use can be in the form of purchases from parties who will manage it to the regional government or the community, there is also a form of regional giving. Regional intangible assets if managed productively will have in common with impact investing, i.e. investments that are directed to have positive social or environmental impacts in addition to economic benefits. In other words, the social and environmental benefits that exist are not just intentional externalities, but the purpose of the investment [17].

The structuring of strategic areas which are a tangible form of civil-military cooperation and other economic strategic areas needs to be optimized through productive management with orientation to positive impacts on the economy, social, and environment and based on juridical rules that apply to the State with the use of technology so that data management going well, effectively and efficiently. This is a positive form of externality from the impact of defense activities, in this case, the Navy in Sorong City, the results of which can be felt and utilized by the Sorong community, local government, and all business people there. Of course in the case of externalities as a negated impact when the role of peace enforcement of the Navy is not achieved in controlling conflict will lead to negative externalities. As a result, from various social instability that will add burden in the form of costs which in the end will become the burden of the cost structure. The problem is, the negative externalities that occur due to conflicting costs which are a burden cannot be determined to whom it is fully responsive (Yusgiantoro, 2014). In fact, if cooperation in the defense sector cannot be carried 
out properly, the regional government will bear more of the negative impact of externalities due to conflict, while conflict makers will likely ignore this impact.

The very principle difference between an agrarian-oriented nation and a maritimeoriented nation is that an agrarian nation always looks inward, so that it utilizes all resources on land, this if it continues to occur will potentially lead to communal conflict due to the need for clothing, food, the board and the development of population growth will be crowded on land, so that the need for space will be increasingly narrow, whereas a maritime-oriented nation will always look outward, a logical consequence if a nation with outward-looking views is able to relate to other nations so that the space for clothing, food, shelter, and population growth will be wider. If this happens then the Indonesian nation as a nation characterized by the archipelago supported by a maritime spirit will be able to build its glory.

The strength development by the Indonesian Navy that reached the eastern part of Indonesia at least helped change the socio-economic order in the people of Sorong City, as well as changes in market conditions there. Increasing the number of military personnel will increase the population of Sorong City, most will bring different culture, and changes in the population will continue to occur along with social interactions. Interaction is part of the social process of how society affects the economy and how the economy affects society [12]. This pattern occurred before during the industrial revolution in Europe in the 18th century, one of which was due to external factors driven by technological inventions so that the process of industrialization grew rapidly. The development of the times changed the behavior and habits of the residents of the city of Sorong and migrants in the city of Sorong so that the initial formation of traditional socio-economics is now increasingly complex in the current post-modern era.

Indonesian Navy personnel and other migrants are faced with a variety of market limitations so that the diverse demands are not enough to be met by local producers. This certainly changes the pattern of market interactions that used to be supply-driven, which is interpreted by producers as still price takers or price leader in the market without having to pay attention to the details of the market wants and needs. If previously the producer could only impose his will on consumers, the next thing that happened in the future was the opposite, consumers who would impose their will on producers or producers now preferred to produce based on consumer demand (demand-driven). ${ }^{10}$ This means that changes in socioeconomic conditions are quite complicated because of the consumption patterns of modern post-industrial societies who prefer to look for producers who are able to provide for their needs.

In the end, changes in social interaction that affect the economy on a small scale also influence the mindset of the people in Sorong City as individual market participants ${ }^{11}$ Judging from the changes that occur in the household sector, it will rationally provide opportunities for adding value to various factors of production owned by households such as land. The social conditions of the Sorong community that are still very strong in holding customary rules still uphold land ownership based on lineage, these conditions have been paid a lot in the past five years since more and more people have entered Sorong. ${ }^{12}$ Factors of community expectations of an increase in the value of selling land make customary law softened due to rational decisions of economic behavior to expect compensation for production factors in the form of rent or high land prices. This activity is referred to as the interaction of economic actors as illustrated in the following diagram in Figure 5.

${ }^{10}$ Aris Arif M, personal communication, August 2018

${ }^{11}$ Herlin Sasabone, personal communication, November 29, 2018

${ }^{12}$ Ariawan, personal communication 29 November 2018 


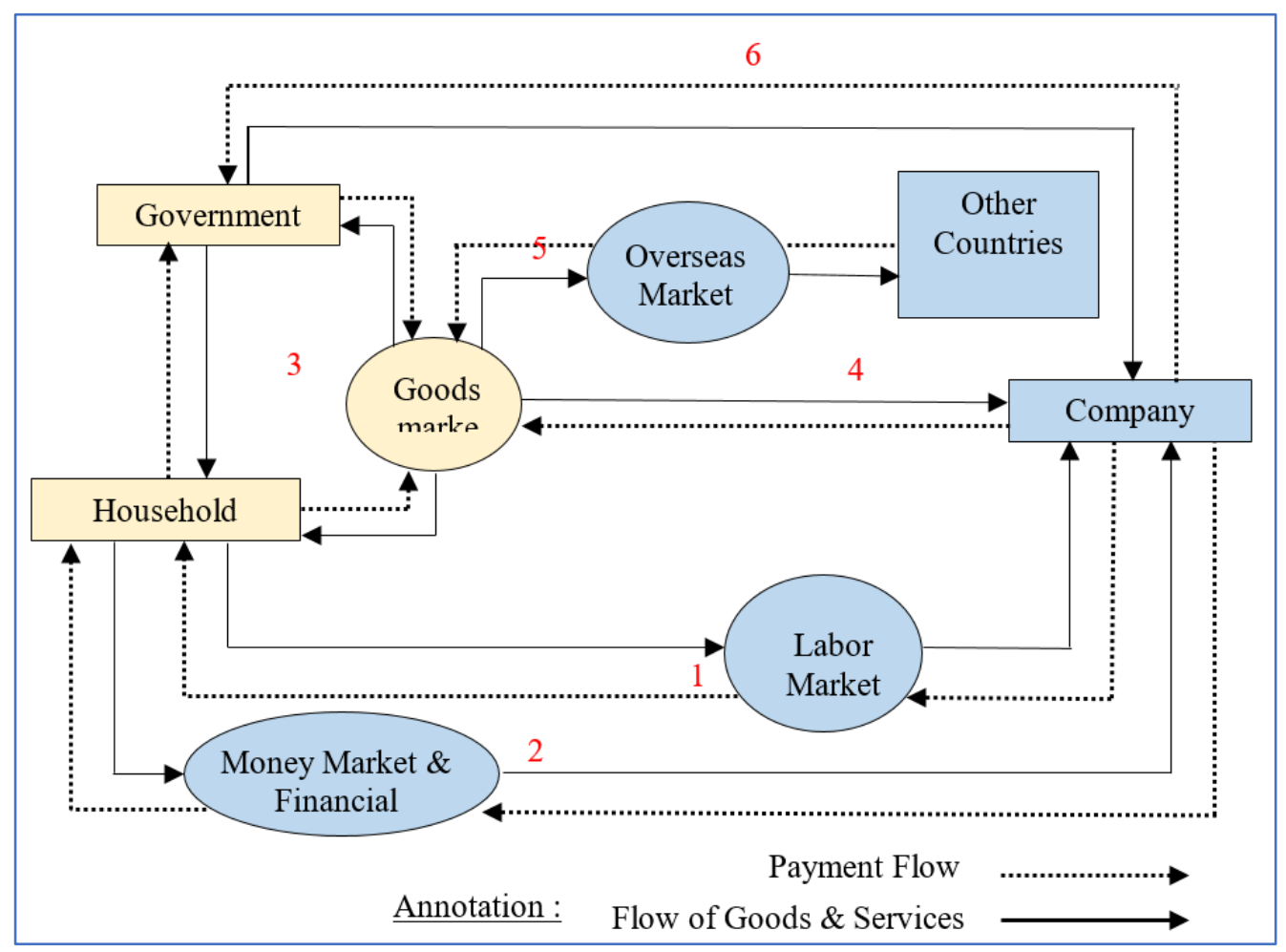

Fig 5. Sectors circular flow [13]

The diagram above illustrates the economic sectors that will appear in Sorong City with the presence of the Navy. Various sectors will grow in line with the increase in the number of troops, with various social interactions carried out by economic actors from the local government, TNI AL soldiers, the community, the industrial sector, and visitors who come to Sorong City will form four economic sectors. This phenomenon is called as a change in market typology [14]. The sociological perspective sees this phenomenon as a collection of events in which a market is formed due to the individual, interest in the same field, ethnicity, race, salary, and so on. While the economist's perspective considers this phenomenon to be formed due to the existence of the industrial sector accompanied by the demand and supply of labor at a certain time.

Market typology can change due to various external factors including changes in the security level of an area will affect the tastes and expectations of the market that will be formed. In the closed market conditions as contained in the orange diagram section gives an initial projection of the formation of traditional markets, in the development of consumption patterns of the people of Sorong City which are still homogeneous have a taste for consumption that tends to be the same and almost does not have a significant difference, so that the demand and supply of goods and services limited to certain needs. The openness of the community took part in the expansion of the market, however, a fairly closed area was not 
easy to open up, the role of the government needed for regional development in this case the government set up a naval military base in Sorong. Population development also influences changes in market typology so that the right-hand side slowly forms new markets due to the entry of new people so as to create a variety of new jobs and diverse demands for labor.

The presence of the Navy's military base and the addition of the number of Navy personnel have influenced changes in the level of security and reduced horizontal conflict, where the security factor in conflict-prone areas is one of the considerations of investors conducting business activities. Along with the increasing population of an area will also increase the level of complexity of community activities. Neither is the case with the industries in it which serve as a place to serve the provision of community needs. Simultaneously, the 4 sectors of the more complex economy were formed and considered capable of being an ideal forum for a diversity of demand and supply. In contrast to economic activities in general, through an economic approach to defense, the formation of this market can occur due to conflict and security factors where if an area of conflict occurs that war can change the strategic position of the enemy with a long-term perspective, which is different from a short-term perspective. As an implication, the defense industry in the region will be much affected by the dynamics that occur, this will also affect the financial cycle and the unemployment rate.

Exchange and trade effect and are affected by conflict. When cross-border trade is not safe, but domestic trade is safe, each party involved in the business will choose autarchy or not trade with other countries. ${ }^{13}$ Implementing an autarchy in a regional economy is seen as limiting productivity opportunities because the costs of law enforcement will be higher and generally burden economic stability. The existence of conflict or unsafe conditions in Sorong will help explain the occurrence of restrictions on the exchange, which cannot be explained when property rights can be carried out perfectly and without cost or minimal costs when in a state of peace / without conflict. The development of an increasingly open era will not allow even conflicting regions to carry out economic autarchy, as well as Sorong, with homogeneity even though local governments must keep the economy open to become an open path so that the economic sector continues to run.

As a state agency, the Navy in carrying out peace enforcement in Sorong simultaneously provides a socio-economic impact on the formation of market typologies and open cooperation both at home and abroad in various fields. Regional economic stability is an implication that can explain how regional security can affect the development of business and other economic sectors through the flow chart above.

\section{Conclusion}

As we can see how conflicts are made by the actors it is all need to be solved, longstanding conflicts due to social inequality are often a significant problem in eastern Indonesia this is also due to economic disparities with such a large gap for Papua, especially in Sorong City. Through the cooperation between military and local government shows how the defense instrument has to do with the process of social and economic change in an area with certain conditions prevailing at that time. The Navy can contribute not only to maritime security, but the paradigm of the community and local government on the importance of defense can make

${ }^{13}$ Yusgiantoro, Purnomo.: Ekonomi Pertahanan. Jakarta: PT. Gramedia Pustaka Utama. P.509 (2014) 
a stable area of security capable of encouraging the productivity of its people so that the economy can run well. However, social stability has depended on economic stability. The military's role in social stability control is now one of the considerations of the central government to support regional stability, especially in the enforcement of sovereignty and countering threats, with this cooperation with government and society will provide benefits not only to the organization but also to the local economy.

\section{References}

[1] Khisty, Jotin.: Soft-Systems Methodology As Learning And Management Tool. Journal of Urban Planning and Development 121(3) 4. (1995)

[2] Salner, M.: Beyond Checkland and Scholes: Improving SSM. Paper presented at the International Conference of the System Dynamics Society, Wellington, New Zealand. (1999)

[3] Hardjosoekarto, Sudarsono.: Soft Systems Methodology (Metode Serba Sistem Lunak). Jakarta: UI-Press. (2012)

[4] Checkland, Peter.: Soft System Methodology in Action. Denmark: University Aalborg. P. 16 (1991)

[5] Checkland, P., \& Poulter, J.: Learning for action: A short definitive account of Soft Systems Methodology and its use for practitioners, teachers and students. Chichester, United Kingdom: Wiley. (2006)

[6] Proches, Gerwel, and Bodhyana.: An Application of Soft Systems Methodology in the Sugar Industry. International Journal of Qualitative Methods. (2015)

[7] Creswell, John W.: Research Design : Pendekatan Kualitatif, Kuantitatif, dan Campuran. Jakarta: Pustaka Remaja. (2016)

[8] Indonesian Navy Headquarters: Eastern Fleet Command: Academic Paper on the Establishment of Koarmada III in Sorong. Jakarta: Indonesian Navy Headquarters. P.5. (2018)

[9] Law of Republic of Indonesia Number 34 Year 2005 on Indonesian Armed Forces.

[10] Yusgiantoro, Purnomo.: Ekonomi Pertahanan. Jakarta: PT. Gramedia Pustaka Utama. (2014).

[12] Cohen, Burce and Orbuch, Terri.: Introduction to Sociology. Newyork: McGraw-Hill. (1989).

[13] Mankiew, N. Gregory.: Makro Ekonomi. Edisi keenam. Jakarta: Penerbit Erlangga. (2007)

[14] Streeck, Wolfgang.: The sociology of labor markets and trade unions. In Neil J. Smelser \& R. Swedberg (ed), The handbook of economic sociology. UK: Princeton University Press. ch. 12 p.254. (2005).

[15] Weber, Albert. (1929). Alfred Weber's Theory Of The Location Of Industries. Chicago, Illionis: The Chicago University Press.

[16] Bagian Tata Ruang Dan Wilayah BAPPEDA Kota Sorong. Buku Rencana: Rencana Tata Ruang dan Wilayah (RTRW) Kota Sorong 2014-2034. Kota Sorong: Pemda Kota Sorong. (2018).

[17] IICPSD \& IDB: Raditya Sukmana's Speech Manuscript at the inauguration ceremony of a professor at Airlangga University, Surabaya 22 June 2019. 